\title{
UJI AKTIVITAS ANTIOKSIDAN, TOKSISITAS, DAN SITOTOKSISITAS EKSTRAKALGA MERAH Rhodymenia palmata
}

\author{
Thamrin Wikanta, Hedi Indra Januar, dan Muhammad Nursid`
}

\begin{abstract}
ABSTRAK
Riset tentang aktivitas antioksidan, toksisitas dan sitotoksisitas ekstrak Rhodymenia palmata telah dilaksanakan. Uji aktivitas antioksidan dilakukan dengan metode DPPH (1,1- difenil-2pikrilhidrazil). Uji toksisitas terhadap Artemia salina dilakukan dengan metode BSLT (Brine Shrimp Lethality Test). Uji sitotoksisitas terhadap sel lestari tumor HeLa ditentukan dengan metode MTT (3-(4,5-dimetilthiazol-2yl)-2,5-difenil tetrazolium bromida). Hasil uji menunjukkan bahwa ekstrak kasar metanol memiliki aktivitas antioksidan rendah $\left(\mathrm{IC}_{50}=464,89 \mathrm{ppm}\right)$. Fraksi etil asetat memiliki toksisitas paling tinggi $\left(\mathrm{LC}_{50}=5,36 \mathrm{ppm}\right)$, dan fraksi $\mathrm{n}$-heksana memiliki toksisitas rendah $\left(\mathrm{LC}_{50}=55,20 \mathrm{ppm}\right)$, sedangkan fraksi metanol termasuk kelompok tidak toksik $\left(\mathrm{LC}_{50}=39012,95\right.$ ppm). Uji sitotoksisitas terhadap sel lestari tumor HeLa menunjukkan bahwa fraksi etil asetat memiliki sitotoksisitas rendah $\left(\mathrm{LC}_{50}=432,43 \mathrm{ppm}\right)$, sedangkan fraksi $\mathrm{n}$-heksana memiliki sitotoksisitas tinggi $\left(\mathrm{LC}_{50}=29,68 \mathrm{ppm}\right)$.
\end{abstract}

\section{ABSTRACT: The assays of the antioxidative activity, toxicity, and cytotoxicity of the red algae Rhodymenia palmata extract. By: Thamrin Wikanta, Hedi Indra Januar, and Muhammad Nursid}

Research on the antioxidative activity, toxicity and cytotoxicity assays of Rhodymenia palmata extract has been carried out. Antioxidative activity assay was conducted using DPPH (1.1-diphenyl-2-picrylhydrazyl) method. Toxicity assay against Artemia salina was performed using the BSLT (Brine Shrimp Lethality Test) method. Cytotoxicity assay against HeLa tumor cell line was determined using MTT [3-(4.5-dimethylthiazol-2yl)-2.5-diphenyl tetrazolium bromide] method. The results showed that methanol crude extract had low antioxidative activity $\left(I C_{50}=464.89 \mathrm{ppm}\right)$. Ethyl acetate fraction had the highest toxicity $\left(L C_{50}=5.36 \mathrm{ppm}\right)$, and $n$-hexane fraction had low toxicity $\left(L C_{50}=55.20 \mathrm{ppm}\right)$. While, methanol fraction belonged to the nontoxic group $\left(L C_{50}=39012.95\right.$ $\mathrm{ppm})$. Cytotoxicity assay against HeLa tumor cell line showed that the ethyl acetate fraction had low cytotoxicity $\left(L C_{50}=432.43 \mathrm{ppm}\right)$, but $n$-hexane fraction had high cytotoxicity $\left(L C_{50}=29.68 \mathrm{ppm}\right)$.

KEYWORDS: Rhodymenia palmata, antioxidative activity, cytotoxicity

\section{PENDAHULUAN}

Penyakit tumor menduduki peringkat pertama sebagai penyebab kematian di dunia. Berbagai usaha telah dilakukan para ilmuwan untuk menemukan obat antitumor, baik sebagai penghambat berkembangnya sel tumor maupun pemusnah sel tumor. Salah satu sumber obat yang banyak dieksplorasi adalah berasal dari bahan alam laut, baik dari tumbuhan, hewan, maupun mikroba. Banyak literatur yang menyatakan bahwa biota laut mengandung berbagai jenis senyawa yang mempunyai aktivitas sebagai antitumor (Kamiya et al., 1987; Schmitz et al., 1993) dan antiviral (Rinehart et al., 1993; Jha \& Zi-rong, 2004). Salah satu penyebab tumor adalah terjadinya akumulasi radikal bebas yang berlebihan sehingga tubuh tidak mampu menetralkannya (Panichayupakaranant \& Kaesuwan, 2004). Studi-studi tersebut memperlihatkan bahwa lingkungan laut merupakan sumber yang kaya akan bahan metabolit sekunder, banyak di antaranya memiliki struktur kimiawi yang tidak ditemukan pada senyawa dari biota yang hidup di lingkungan terestrial (Jadulco, 2002).

Indonesia sebagai salah satu negara yang memiliki diversitas sumberdaya hayati laut tertinggi di dunia menyimpan potensi yang sangat besar sebagai penghasil bahan obat untuk menghambat berkembangnya tumor dan membunuh tumor. Potensi rumput laut atau alga yang dimiliki Indonesia sangat besar untuk dikembangkan sebagai bahan baku obat. Selama ini pemanfaatan dalam bidang farmasi masih sangat terbatas. Pemanfaatan secara massal adalah sebagai sumber agar, karaginan dan alginat yang merupakan metabolit primer. Untuk pemanfaatan metabolit sekundernya masih sangat terbatas bahkan belum berkembang.

Dalam pengobatan tradisional, rumput laut atau alga telah lama digunakan untuk keperluan pengobatan berbagai jenis penyakit, seperti anti-

\footnotetext{
-) Peneliti pada Pusat Riset Pengolahan Produk dan Sosial Ekonomi Kelautan dan Perikanan
} 
curare,-penurun panas, eksim, batu empedu, gondok, gangguan menstruasi, gangguan ginjal, scabies, dan scrofula. Tampaknya manfaat yang bervariasi ini telah mendorong para ahli untuk mencari kemungkinan obat antitumor dari tanaman laut tersebut (Angka \& Suhartono, 2000).

Menurut Shoeib et al. (2004), telah ditemukan senyawa dari ekstrak alga yang memiliki aktivitas antitumor yaitu senyawa lanosol dan derivatnya, senyawa tersebut termasuk golongan fenol terhalogenasi. Namun mekanisme kerja senyawa tersebut terhadap sel lestari tumor belum diketahui. Dikemukakan oleh Meyer (1999) bahwa hasil uji farmakologi senyawa antitumor dari ekstrak alga yang telah diketahui mekanisme kerjanya, di antaranya adalah: Curacin D (poliketida), Dehydrothyrsiferol (terpenoid), Spirulan (polisakarida), Stypodiol (terpenoid), dan Tolyporphin (pyrrol), dan yang belum diketahui mekanisme kerjanya adalah Cryptoxanthin (terpenoid).

Alga merah jenis Rhodymenia palmata (Linnaeus) Greville tumbuh di rataan terumbu karang, umumnya pada substrat batu di bagian sisi luar rataan terumbu yang biasa terkena ombak langsung. Kebanyakan terdapat di pantai Samudra Hindia seperti di pantai Selatan Jawa dan Selatan Bali. Alga merah ini mengandung pigmen fotosintetik berupa karoten, xantofil, fikobilin terutama r-fikoeretrin penyebab warna merah, dan klorofil a dan b. Dalam dinding šelnya terdapat selulosa dan produk fotosintetik berupa karaginan, agar dan furselaran. Alga merah ini akan mengalami perubahan warna dari warna aslinya menjadi warna ungu apabila alga tersebut terkena panas sinar matahari secara langsung (Atmadja et al., 1996).

Riset ini bertujuan untuk mengetahui tingkat bioaktivitas metabolit sekunder hasil ekstraksi dari alga merah jenis Rhodymenia palmata yang banyak tersebar di perairan laut Indonesia dan belum dimanfaatkan secara ekonomi, sebagai upaya mencari kemungkinan didapatkannya senyawa yang potensial sebagai bahan obat antitumor.

\section{BAHAN DAN METODE}

\section{Preparasi Ekstrak Rhodymenia palmata}

Rumput laut R. palmata dipanen dari Pantai Krakal Yogyakarta pada bulan Juni 2004. Sampel segar diambil sebanyak 500 gram kemudian dimasukkan Ke dalam plastik polietilen tahan pelarut organik dan langsung dimaserasi di lapangan dengan menggunakan pelarut metanol sebanyak $800 \mathrm{ml}$. Sampel dimaserasi selama 72 jam, lalu disaring, kemudian dimaserasi kembali selama 24 jam dengan pelarut metanol. Setelah disaring dimaserasi lagi selama 24 jam, kemudian pada hari berikutnya semua ekstrak kasar metanol digabung $(2400 \mathrm{ml})$ dan dievaporasi hingga menjadi $100 \mathrm{ml}$. Ekstrak metanol hasil evaporasi difraksinasi masing-masing dengan pelarut $n$-heksana dan etil asetat sehingga didapatkan 3 fraksi besar : fraksi nonpolar (n-heksana), fraksi semipolar (etil asetat), dan fraksi polar (metanol). Ketiga fraksi ini masing-masing kemudian dievaporasi kembali hingga semua pelarut menguap, lalu dibekukan dan dikeringkan pada suhu rendah menggunakan freeze dryer (untuk fraksi metanol) dan menggunakan nitrogen evaporator (untuk fraksi etil asetat dan n-heksana).

\section{Uji Aktivitas Antioksidan Menggunakan Metode Uji DPPH}

\section{Metode uji kualitatif}

Uji aktivitas antioksidan secara kualitatif dilakukan menggunakan metode yang digunakan Oke \& Hamburger (2002). Satu mg ekstrak dimasukkan ke dalam tabung reaksi, kemudian ditambahkan $10 \mathrm{ml}$ metanol. Ekstrak metanol tersebut ditotolkan pada plat kromatografi lapis tipis (KLT) silika gel dengan jarak $10 \mathrm{~mm}$ dari batas bawah. Noda (spot) tersebut dikeringkan. Fase gerak KLT dibuat dengan campuran metanol dan etil asetat dengan perbandingan 1:1. Selanjutnya dilakukan pengembangan dalam chamber kromatografi dan noda yang terbentuk diperiksa menggunakan semprotan pereaksi 1,1-difenil-2pikrilhidrazil (DPPH) (konsentrasi $10 \mathrm{mg}$ dalam $10 \mathrm{ml}$ metanol). Setelah kering noda yang terbentuk diperiksa menggunakan lampu UV pada panjang gelombang $366 \mathrm{~nm}$ dan $254 \mathrm{~nm}$. Noda hasil berwarna kuning, atau biru, atau ungu-muda, menunjukkan positif adanya antioksidan. Perbedaan warna yang tampak adalah berdasarkan konsentrasi kompleks yang terbentuk antara antioksidan dengan pereaksi DPPH.

\section{Metode uji kuantitatif}

Uji aktivitas antioksidan secara kuantitatif dilakukan menggunakan metode Chow et al. (2003). Satu ml DPPH ditambah metanol hingga menjadi $5 \mathrm{ml}$ (blanko). Sampel ekstrak dibuat dengan 4 seri konsentrasi yaitu $0,5,10$, dan 25 ppm. Tiap sampel ditakar dengan volume yang sama, ditambahkan $1 \mathrm{ml}$ DPPH lalu diencerkan dengan metanol hingga volumenya menjadi $5 \mathrm{ml}$ dan diinkubasi pada suhu $37^{\circ} \mathrm{C}$ selama 30 menit. Uji serapan dilakukan pada panjang gelombang $515 \mathrm{~nm}$. Hambatan (dalam persen) dihitung berdasarkan:\{(serapan blanko-serapan sampel)/ serapan blanko\} x 100\%. Nilai hambatan dan konsentrasi ekstrak diplot masing-masing pada 
sumbu $x$ dan $y$, persamaan garis yang diperoleh digunakan untuk mencari Inhibition Concentration $50 \%$ $\left(\mathrm{IC}_{50}\right)$.

\section{Uji Toksisitas Menggunakan Metode Brine Shrimp Lethality Test (BSLT)}

Uji toksisitas dilakukan menurut metode Meyer et al. (1982), McLaughlin \& Rogers (1998) dan Carballo et al. (2002). Metode BSLT dilakukan untuk memprediksi toksisitas suatu bahan dan digunakan untuk mendeteksi toksin fungal, logam berat, toksin sianobakteria, dan aktivitas pestisida. Metode ini biasa dilakukan dalam uji pendahuluan untuk skrining atau penapisan aktivitas farmakologis pada produk alam (Carballo et al., 2002; Guerrero et al., 2004). Metode BSLT ini juga biasa dilakukan sebagai tahap pendahuluan dalam penapisan bahan-bahan yang diperkirakan memiliki sifat antitumor atau antikanker sebelum melangkah kepada uji in vitro menggunakan sel lestari kanker (Widjhati et al., 2004). Metode BSLT digunakan sebagai bioassay-guided fractionation bahan alam, metode pra skrining penelitian sel tumor di Cell Culture Laboratory of the Purdue Cancer Center, Purdue University (Alam, 2002). Hal ini dilakukan berdasarkan pertimbangan bahwa uji BSLT bersifat mudah dilakukan, cepat, biayanya murah, dapat dilakukan di laboratorium, dan memiliki tingkat kepercayaan tinggi dibandingkan dengan uji in vitro menggunakan sel lestari yang memerlukan biaya sangat mahal dan media serta keterampilan yang khusus (Meyer et al., 1982).

Dalam uji ini digunakan larva Artemia salina sebagai hewan uji. Mula-mula telur $A$. salina ditetaskan di dalam air laut buatan ( $38 \mathrm{~g}$ garam dapur dalam $1000 \mathrm{ml}$ air biasa) di bawah lampu TL 20 watt. Setelah 48 jam telur menetas manjadi nauplii instar III/IV dan siap digunakan sebagai hewan uji. Larva $A$. salina dimasukkan ke dalam vial yang telah berisi larutan ekstrak sampel dengan seri dosis 5, 50, 250, dan 1000 ppm dengan 3 kali ulangan. Semua vial diinkubasi pada suhu kamar selama 24 jam di bawah penerangan lampu TL 20 watt. Pengamatan dilakukan setelah 24 jam dengan melihat jumlah Artemia salina yang mati pada tiap konsentrasi. Penentuan harga $\mathrm{LC}_{50}$ dalam $\mu \mathrm{g} / \mathrm{ml}$ atau ppm dilakukan menggunakan analisis probit dengan program MINITAB versi 13.2 dengan selang kepercayaan $95 \%$.

\section{Uji Sitotoksik Terhadap Sel Lestari Tumor HeLa}

Uji sitotoksisitas dilakukan dengan metode MTT [3-(4,5-dimetilthiazol-2yl)-2,5-difenil tetrazolium bromida] menurut Hughes \& Mehmet (2003). Sel tumor HeLa diperoleh dari koleksi Laboratorium Penelitian dan Pengujian Terpadu (LPPT) UGM. Sel
HeLa dikultur dalam medium RPMI 1640 lengkap, Fetal Bovine Serum (FBS) $10 \%$, fungison $0,5 \%$, dan penisilin-streptomisin $2 \%$.

Ektrak R. palmata yang aktif menurut hasil BSLT, dibuat seri dosis 6,$25 ; 12,5 ; 25 ; 50$; dan 100 ppm dengan 3 kali ulangan. Larutan ekstrak dimasukkan ke dalam microplate 96 sumuran sebanyak $100 \mu \mathrm{L}$. Sel HeLa dimasukkan ke dalam tiap sumuran masingmasing sebanyak $100 \mu \mathrm{L}$. Kontrol perlakuan ada 3 terdiri dari kontrol sel ( $100 \mu \mathrm{L}$ sel $+100 \mu \mathrm{L}$ media), kontrol sampel $(100 \mu \mathrm{L}$ ekstrak $+100 \mu \mathrm{L}$ media) dan kontrol media (200 $\mu \mathrm{L}$ media). Sediaan dalam microplate diinkubasikan selama 24 jam pada suhu $37^{\circ} \mathrm{C}$ dengan aliran $\mathrm{CO}_{2} 5 \mathrm{ml} / \mathrm{menit}$. Setelah 24 jam ke dalam tiap-tiap sumuran ditambahkan MTT sebanyak $10 \mu \mathrm{L}$, diinkubasi kembali pada inkubator $\mathrm{CO}_{2}$ selama 4 jam, kemudian reaksi MTT dihentikan dengan cara menambahkan $100 \mu \mathrm{L}$ sodium dedosil sulfat (SDS) $10 \%$. Microplate diinkubasi kembali selama 12 jam pada suhu kamar. Setelah 12 jam, absorbansi tiap sumuran dibaca dengan spektrofotometer ELISA plate reader pada panjang gelombang $560 \mathrm{~nm}$. Persentase kematian sel HeLa dihitung dengan rumus $(A-B) / A \times 100 \%$, dimana $A$ adalah jumlah sel yang hidup pada sumuran kontrol, dan $B$ adalah jumlah sel yang hidup pada sumuran yang diberi ekstrak uji. Nilai $\mathrm{LC}_{50}(\mu \mathrm{g} / \mathrm{ml}$ atau $\mathrm{ppm})$ dihitung dengan analisis probit menggunakan program MINITAB versi 13.2 dengan selang kepercayaan $95 \%$.

\section{HASIL DAN BAHASAN}

\section{Aktivitas Antioksidan}

Hasil uji penapisan fitokimia untuk mengetahui jenis golongan senyawa yang terkandung dalam ekstrak kasar metanol dari Rhodymenia palmata segar memperlihatkan bahwa ekstrak metanol bersifat positif mengandung golongan senyawa saponin, flavonoid, dan triterpenoid. Uji aktivitas antioksidan dilakukan untuk mengetahui apakah senyawa yang terdapat dalam ekstrak kasar metanol yang diuji memiliki aktivitas antioksidan. Reaksi antara antioksidan dengan radikal bebas didasarkan pada prinsip reaksi penangkapan hidrogen dari antioksidan oleh radikal bebas DPPH. Antioksidan akan mendonorkan proton atau hidrogen kepada DPPH dan selanjutnya akan terbentuk radikal bebas baru yang bersifat stabil atau tidak reaktif. Hal ini dapat dilukiskan dalam persamaan berikut:

$$
\begin{aligned}
& \begin{array}{l}
\mathrm{DPPH}^{*}+\mathrm{AH} \rightarrow \mathrm{DPPH}-\mathrm{H} \\
\text { Radikal bebas antioksidan }
\end{array} \\
& \begin{array}{l}
\text { netral } \\
\text { Warna ungu }
\end{array} \\
& \begin{array}{c}
\text { radikal bebas baru, } \\
\text { stabil, tak reaktif }
\end{array} \\
& \text { Warna Kuning }
\end{aligned}
$$


Reaksi netralisasi radikal bebas DPPH yang menghasilkan perubahan warna seperti dilukiskan dalam persamaan reaksi di atas menjadi dasar pelaksanakan uji daya antioksidan metode DPPH secara kualitatif dan kuantitatif.

Hasil analisis dengan kromatografi lapis tipis terhadap ekstrak kasar metanol yang memiliki aktivitas antioksidan, secara kualitatif memperlihatkan bahwa pelarut pengelusi yang baik untuk mengembangkan ekstrak sampel adalah campuran metanol dan etil asetat dengan perbandingan 1:1. Hal ini menunjukkan bahwa senyawa-senyawa yang terkandung di dalam ekstrak metanol $R$. palmata merupakan senyawa dengan tingkat kepolaran menengah ke atas. Noda yang terbentuk dari kromatografi lapis tipis yang diamati di bawah lampu UV (panjang gelombang 366 dan $254 \mathrm{~nm}$ ) berwarna kuning agak terang. Hal ini secara kualitatif menunjukkan bahwa ekstrak metanol mengandung kromofor atau ikatan rangkap terkonjugasi yang dapat bersifat sebagai antioksidan. Penyemprotan dengan larutan DPPH menunjukkan bahwa secara kualitatif ekstrak metanol tersebut bersifat positif mengandung senyawa antioksidan. Hasil uji secara kualitatif menunjukkan bahwa ekstrak metanol $R$. palmata memiliki senyawa dengan gugus yang mampu melakukan reaksi netralisasi radikal bebas DPPH. Menurut Oke \& Hamburger (2002), suatu senyawa yang mengandung gugus hidroksil, polihidroksil, atau karbonil memiliki aktivitas antioksidan karena senyawa tersebut akan bereaksi dengan radikal bebas melalui mekanisme donor proton dari gugus hidroksil yang terdapat pada senyawa aktif atau senyawa antioksidan tersebut. Untuk mengetahui besarnya daya hambat dari senyawa antioksidan yang terkandung dalam ekstrak metanol tersebut dilakukan uji secara kuantitatif dengan mencari harga $I C_{50}$. Hubungan antara persentase hambatan ekstrak metanol R. palmata terhadap radikal bebas DPPH ditunjukkan oleh persamaan garis seperti disajikan pada Gambar 1.

Berdasarkan persentase hambatan dari tiap konsentrasi ekstrak metanol, selanjutnya dihitung dengan analisis probit dan dihasilkan harga $\mathrm{IC}_{50}$ sebesar $464,89 \mathrm{ppm}$. Hal ini berarti bahwa $50 \%$ radikal bebas DPPH berhasil dihambat oleh ekstrak metanol R. palmata pada konsentrasi ekstrak sebesar 464,89 $\mathrm{ppm}$. Sebagai pembanding digunakan vitamin $C$ yang memiliki $I C_{50}$ sebesar 21,09 ppm (Windono et al., 2001; Maryati, 2004). Berdasarkan hasil tersebut berarti aktivitas antioksidan ekstrak metanol $R$. palmata sangat rendah, berada jauh di bawah aktivitas antioksidan vitamin C. Rendahnya aktivitas antioksidan dari ekstrak kasar tersebut kemungkinan karena aktivitas antioksidan dari senyawa dalam ekstrak tersebut memang benar rendah, atau kadar senyawa antioksidan dalam ekstrak sangat rendah akibat banyaknya komponen lain yang merupakan pengotor atau komponen pengotor yang terdapat di dalam ekstrak masih sangat tinggi. Produk alam dari laut secara umum mengandung kadar garam yang tinggi. Apabila komponen pengotor paling utama yang terdapat dalam ekstrak uji tersebut adalah garam $(\mathrm{NaCl})$, maka perlu upaya desalting terlebih dahulu

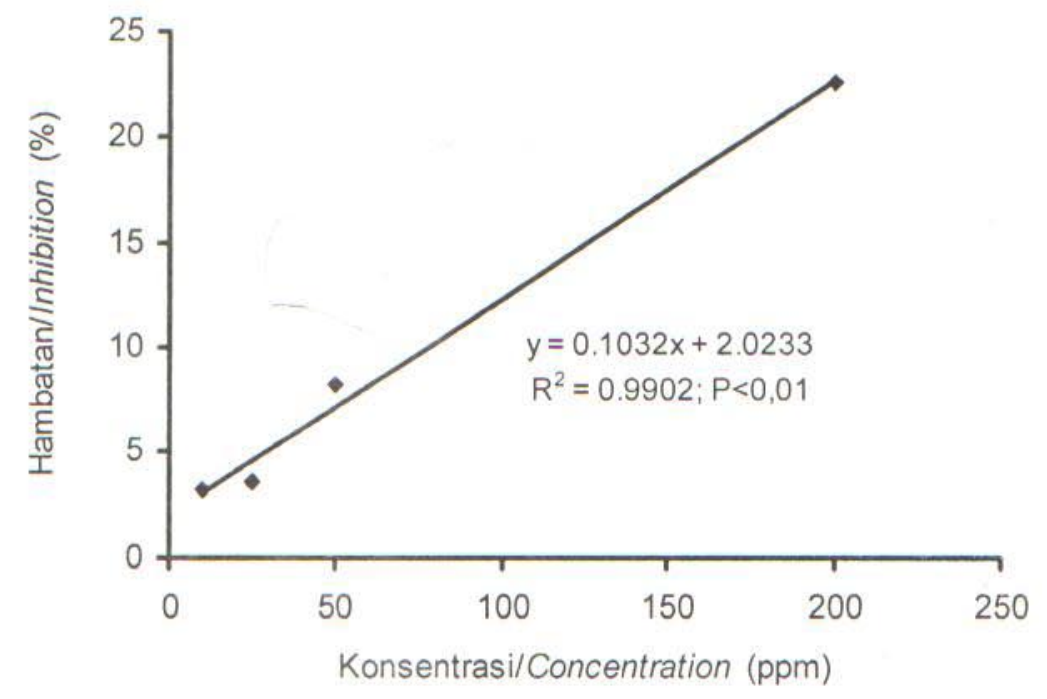

Gambar 1. Aktivitas antioksidan ekstrak metanol dari $R$. palmata terhadap radikal bebas DPPH. Figure 1. Antioxidative activity of $R$. palmata methanol extract against DPPH free radical. 
agar didapatkan bahan aktif yang lebih murni dengan aktivitas antioksidan yang lebih tinggi.

Biota laut memiliki berbagai mekanisme untuk memproteksi dirinya dari sinar UV, di antaranya dengan memiliki UVAS (UV-absorbing substance) yang menghambat penetrasi sinar UV ke dalam jaringan atau sel, sehingga memproteksi DNA. Hasil identifikasi menunjukkan bahwa UVAS dalam alga adalah asam amino serupa mycosporin yang memiliki $\lambda_{\text {maksimum }} 300-350 \mathrm{~nm}$, dan terutama mengabsorbsi UV-B dan UV-A. Alga laut yang terkena sinar UV kuat, seperti yang hidup di laut dangkal akan memiliki kandungan UVAS lebih tinggi dibandingkan dengan yang hidup di laut dalam (Misonou et al., 2003).

\section{Toksisitas Terhadap Artemia salina}

Uji toksisitas ekstrak $R$. palmata fraksi metanol, etil asetat, dan n-heksana dilakukan terhadap Artemia salina (BSLT). Suatu ekstrak dianggap sangat toksik apabila memiliki nilai LC $_{50}$ (Lethal Concentration 50\%) di bawah 30 ppm, dianggap toksik bila memiliki nilai $\mathrm{LC}_{50}$ antara 30-1000 ppm, dan dianggap tidak toksik bila memiliki nilai LC $_{50}$ di atas 1000 ppm (Meyer et al, 1982). Hasil uji toksisitas dari ekstrak R. palmata fraksi metanol, etil asetat, dan $n$-heksana terlihat pada Gambar 2 dan Tabel 1

Fraksi etil asetat memiliki toksisitas yang paling tinggi dengan nilai $\mathrm{LC}_{50}$ sebesar 5,36 ppm, diikuti oleh fraksin-heksana dengan nilai $\mathrm{LC}_{50}$ sebesar 55,20 ppm, kemudian fraksi metanol yang bersifat tidak toksik dengan nilai LC $_{50}$ sebesar 39012,95 ppm. Berdasarkan nilai toksisitas dari tiap fraksi tersebut selanjutnya dilakukan uji sitotoksisitas fraksı etil asetat dan nheksana terhadap sel lestari tumor HeLa, untuk melihat kemungkinan adanya korelasi antara hasil uji toksisitas terhadap Artemia salina dengan uji sitotoksisitas terhadap sel lestari tumor HeLa. Uji

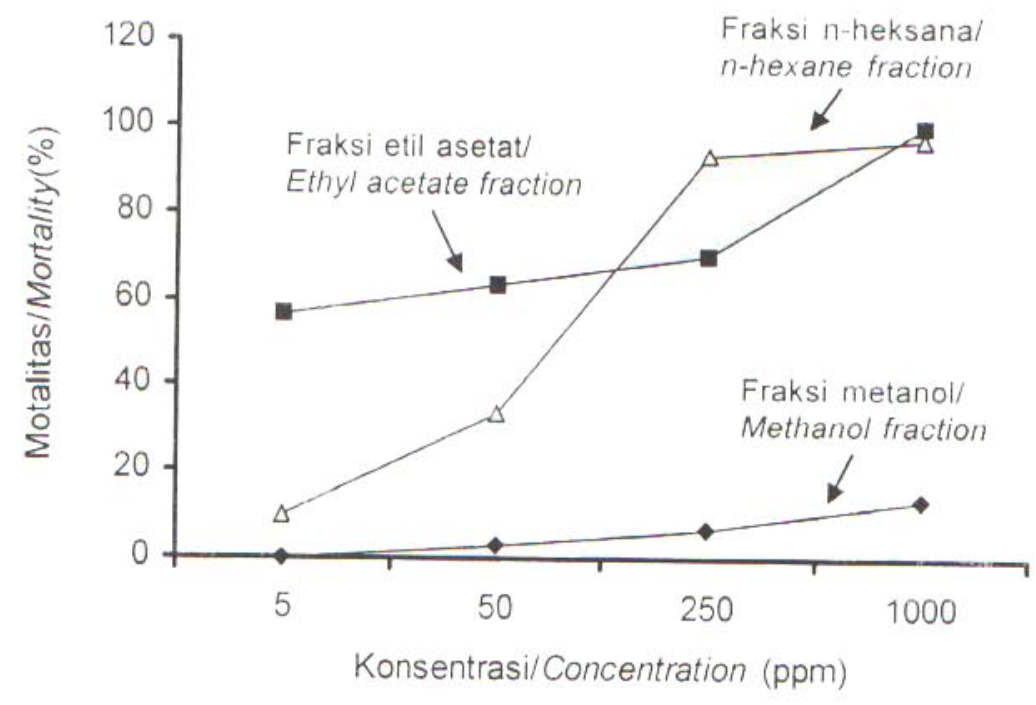

Gambar 2. Mortalitas A. salina (\%) oleh fraksi metanol, etil asetat, dan n-heksana dari ekstrak $R$. palmata Figure 2. The mortality of $A$. salina (\%) against the methanol, ethyl acetate, and $n$-hexane fraction of $R$. palmata extract.

Tabel 1. Hasil BSLT (nilai LC L $_{50}$ ) fraksi metanol, etil asetat, dan n-heksana dari ekstrak R. palmata. Table 1. BSLT result ( $L C_{50}$ value) of methanol, ethyl acetate, and $n$-hexane fraction of $R$. palmata extract.

\begin{tabular}{cc}
\hline Fraksi/Fraction & $\mathrm{LC}_{50}(\mathrm{ppm})$ \\
\hline Metanol/Methanol & 39012.95 \\
Etil asetat/Ethyl acetate & 5.36 \\
n-heksana/n-hexane & 55.2 \\
\hline
\end{tabular}




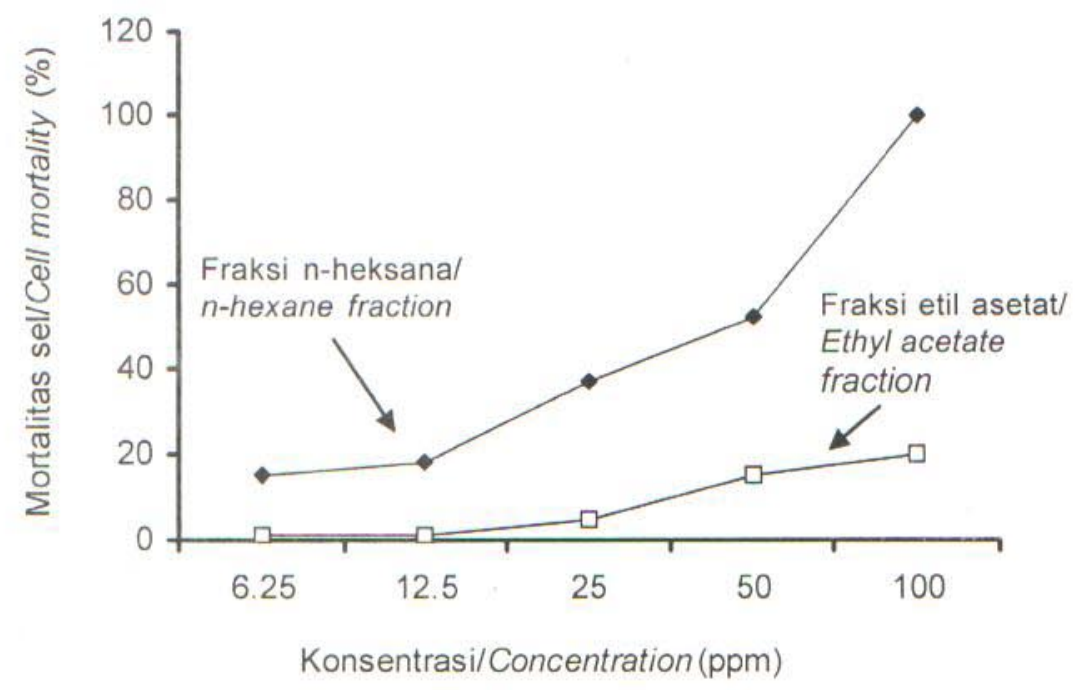

Gambar 3. Mortalitas sel lestari tumor HeLa oleh fraksi etil asetat dan n-heksana dari ekstrak R. palmata. Figure 3. The mortality of HeLa tumor cell line against the ethyl acetate and n-hexane fraction of $R$. palmata extract.

aktivitas fraksi metanol terhadap sel lestari HeLa tidak dilakukan karena dianggap tidak prospektif.

\section{Sitotoksisitas Terhadap Sel Lestari Tumor HeLa}

Sitotoksisitas ditentukan dengan menggunakan sel lestari tumor HeLa. Sel HeLa berasal dari sel kanker leher rahim manusia (human cervix epitheloid carcinoma). Sel ini diisolasi pada tahun 1951 dari seorang wanita penderita kanker leher rahim bernama Henriatta Lacks yang berusia 30 tahun (Dai, 2004).

Uji sitotoksisitas dengan metode MTT merupakan uji kolorimetri kuantitatif berdasarkan pada absorpsi warna larutan hasil pemecahan garam tetrazolium berwarna kuning yang larut dalam air menjadi tidak larut dalam air (dalam bentuk kristal formazan) berwarna biru gelap. Kristal formazan dilarutkan dalam pelarut organik isopropanol. Absorbansi yang dihasilkan berbanding lurus dengan konsentrasi larutan biru formazan yang menggambarkan aktivitas metabolisme sel (Hughes \& Mehmet, 2003).

Berdasarkan nilai absorbansi yang diperoleh dari uji dengan metode MTT, maka ditentukan persentase sel yang mati akibat pengaruh pemberian suatu ekstrak. Persentase kematian sel HeLa setelah perlakuan ekstrak etil asetat dan n-heksana dengan berbagai konsentrasi disajikan pada Gambar 3 dan Tabel 2. Terlihat bahwa pada konsentrasi 100 ppm ekstrak R. palmata fraksi etil asetat hanya mampu membunuh sel HeLa sekitar $20 \%$ sedangkan fraksi n-heksana dapat membunuh hampir $100 \%$ sel HeLa. Efek sitotoksik suatu bahan alam dapat dilihat dari nilai $\mathrm{LC}_{50}$.

Hasil analisis probit memperlihatkan bahwa fraksi etil asetat memiliki nilai $L C_{50}$ sebesar 432,43 ppm, sedangkan fraksi n-heksana memiliki nilai $L_{50}$

Tabel 2. Mortalitas sel lestari tumor HeLa terhadap $\left(L_{50}\right)$ fraksi etil asetat, dan $n$-heksana dari ekstrak $R$. palmata.

Table 2. The mortality of HeLa cell line ( $L C_{50}$ value) against ethyl acetate, and n-hexane fraction of $R$. palmata extract.

\begin{tabular}{cc}
\hline Fraksi/Fraction & LC $_{50}(\mathrm{ppm})$ \\
\hline Etil asetat/Ethyl acetate & 432.43 \\
n-heksana/n-hexane & 29.68 \\
\hline
\end{tabular}


sebesar 29,68 ppm. Berdas - rkan nilai LC $_{50}$ tersebut, maka ekstrak $R$. paimata fraksi n-heksana memiliki prospek yang baik untuk diteliti lebih lanjut efek sitotoksiknya terhadap proliferasi sel lestari tumor HeLa. Dalam hal ini tidak terlihat korelasi yang positif antara hasil uji toksisitas dengan hasil uji sitotoksisitas. McLaughlin \& Rogers (1998) mengemukakan bahwa ada korelasi positif antara hasil uji toksisitas metode BSLT dengan uji sitotoksisitas terhadap sel lestari tumor human nasopharyngeal carcinoma. Sedangkan Carballo et al. (2002) yang membandingkan hasil uji sitotoksisitas dengan sel lestari human lung carcinoma dan human colon carcinoma dengan hasil uji BSLT, mengemukakan bahwa kedua uji memiliki korelasi yang rendah untuk dosis di bawah 100 ppm tetapi untuk dosis 1000 ppm uji toksisitas konsisten dengan uji sitotoksisitas.

\section{Analisis GC-MS Fraksi n-heksana}

Berdasarkan hasil penapisan fitokimia, kemungkinan senyawa yang terdapat dalam fraksi nheksana adalah golongan terpenoid, sedangkan golongan flavonoid dan polifenol kemungkinan terdapat pada fraksi etil asetat. Hasil analisis kromatografi terhadap fraksi n-heksana menggunakan GC-MS menunjukkan bahwa dalam fraksi tersebut terdapat 20 komponen, seperti terlihat pada Tabel 3. Berdasarkan data spektra fragmentasi komponenkomponen yang ada serta berdasarkan data pustaka yang tersedia dalam instrumen GC-MS, terlihat ada 6 komponen $(4,5,7,8,9$, dan 20) atau senyawa yang bersifat sebagai khromofor atau memiliki ikatan rangkap terkonjugasi (memiliki inti benzena dan adanya gugus karbonil atau hidroksil yang terikat pada inti benzena), yang diduga memiliki sifat sebagai antioksidan dan berperan sebagai antitumor. Namun di antaranya terdapat 3 komponen yang sama $(7,8$, dan 9), hanya sedikit berbeda dalam waktu retensi, jadi diduga hanya ada 4 senyawa yang aktif. Di antara 4 senyawa yang diduga aktif, 3 senyawa merupakan homolog senyawa benzen dikarboksilat (senyawa lemak yang memiliki inti benzen), kecuali senyawa 5 yang merupakan derivat senyawa fenol. Ketidaksesuaian hasil uji fitokimia dengan hasil analisis GCMS diduga karena daftar senyawa yang terdapat

Tabel 3. Kemungkinan senyawa pada fraksi heksana dari hasil analisis GC-MS

Table 3. The estimated compounds in the hexane fraction of the GC-MS analysis

\begin{tabular}{|c|c|c|c|c|}
\hline $\begin{array}{l}\text { Puncak/ } \\
\text { Peak }\end{array}$ & $\begin{array}{l}\text { Waktu retensi/ } \\
\text { Retention time } \\
\text { (Menit/Minute) }\end{array}$ & $\begin{array}{c}\text { Luas } \\
\text { puncak/ } \\
\text { Peak area } \\
(\%)\end{array}$ & $\begin{array}{c}\text { Berat } \\
\text { molekul/ } \\
\text { Molecular } \\
\text { weight }\end{array}$ & $\begin{array}{l}\text { Kemungkinan nama senyawal } \\
\text { Estimated compound name }\end{array}$ \\
\hline 1 & 5.134 & 5.96 & 243 & [(2-fluorophenyl)methyl]-1-purin-6-amine \\
\hline 2 & 20.487 & 1.01 & 444 & Dodecamethyl-cyclohexasiloxane \\
\hline 3 & 22.261 & 1.14 & 198 & n-Tetradecane \\
\hline 4 & 22.716 & 1.92 & 194 & $\begin{array}{l}\text { Dime thyl ester-1,2-benzenedicarboxylic } \\
\text { acid, }\end{array}$ \\
\hline 5 & 24.814 & 1.21 & 220 & 4-Methyl-2,6-di-tert-butylphenol \\
\hline 6 & 24.94 & 0.79 & 268 & 2,6,10,14-tetramethyl-pentadecane \\
\hline 7 & 25.725 & 3.08 & 222 & Diethyl ester-1,2-benzenedicarboxylic acid \\
\hline 8 & 26.182 & 29.44 & 222 & Diethyl ester-1,2-benzenedicarboxylic acid \\
\hline 9 & 28.436 & 13.53 & 222 & Diethyl ester-1,2-benzenedicarboxylic acid \\
\hline 10 & 29.425 & 1.52 & 268 & n-Nonadecane \\
\hline 11 & 29.606 & 1.29 & 242 & Methyl ester tetradecanoic acid, \\
\hline 12 & 34.967 & 13.21 & 270 & Hexadecanoic acid, methyl ester \\
\hline 13 & 35.684 & 2.37 & 256 & Hexadecanoic acid \\
\hline 14 & 38.689 & 2 & 296 & Methyl ester-9-octadecanoic acid \\
\hline 15 & 39.059 & 2.36 & 296 & Phytol \\
\hline 16 & 41.358 & 9.41 & 318 & Methyl arachidonate \\
\hline 17 & 44.175 & 1.24 & 280 & tert-Buthyl (E)-3-(trifluoromethyl)-2-decanoate \\
\hline 18 & 44.358 & 1.47 & 296 & Octamethyl-cyclotetrasiloxane \\
\hline 19 & 44.417 & 1.46 & 296 & Octamethyl-cyclotetrasiloxane \\
\hline 20 & 44.898 & 5.6 & 390 & $\begin{array}{l}\text { Diisooctyl ester-1,2-benzenedicarboxylic } \\
\text { acid }\end{array}$ \\
\hline & Total & 100 & & \\
\hline
\end{tabular}


dalam pustaka GC-MS sangat terbatas, tidak memiliki daftar senyawa terpenoid. Ditinjau darı sudut aktivitas. fraksi heksan memiliki toksisitas yang relatif rendah tetapi memiliki sitotoksisitas yang relatif tinggi. Suatu kemungkinan adalah senyawa-senyawa tersebut bekerja sinergis sebagai antiproliferasi dan apoptotik terhadap sel tumor HeLa Untuk mengetahui secara pasti, komponen atau senyawa yang dapat bekerja sebagai antiproliferasi dan apoptotik terhadap sel lestari tumor HeLa maka sedang dilakukan penelitian lanjutan untuk pemurnian atau isolasi masing-masing komponen menggunakan kromatografi kolom gravitasi dan kromatografi cair kinerja tinggi (HPLC), dan dilanjutkan dengan pengujian masing-masing komponen terhadap sel lestari HeLa, yang hasilnya akan disampaikan pada laporan berikutnya. Untuk mengetahui mekanisme kerja dari senyawa tersebut. pada fase mana bekerjanya dalam siklus sel ( $S, G 0$, G1, M, G2) maka perlu pengujian lanjutan menggunakan metode sitometri

\section{KESIMPULAN}

Berdasarkan penelitian yang telah dilakukan dapat disimpulkan bahwa

1. Hasil uji aktivitas antıoksidan menunjukkan bahwa ekstrak kasar metanol dari alga merah R. palmata tidak potensial sebagai bahan baku antioksidan

2. Hasil uji toksisitas terhadap Artemia salina menunjukkan bahwa ekstrak alga merah $R$. palmata fraksi etil asetat memiliki toksisitas yang paling tinggi, diikuti oleh fraksi n-heksana dan fraksi metanol.

3. Hasil uji sitotoksisitas terhadap sel lestari tumor HeLa menunjukkan bahwa ekstrak alga merah $R$. palmata, fraksi n-heksana memiliki sitotoksisitas yang paling tinggi, diikuti oleh fraksi etil asetat

4. Hasil analisis kromatografi dengan GC-MS terhadap fraksi n-heksana menunjukkan bahwa dalam fraksi tersebut terdapat 4 komponen senyawa yang bersifat sebagai kromofor atau memiliki ikatan rangkap terkonjugasi, yang dapat berperan sebagai antioksidan dan diduga bersifat sebagai antiproliferasi terhadap sel lestari tumor HeLa.

\section{DAFTAR PUSTAKA}

Alam, G. 2002. Brine Shrimp Lethality Test (BST) sebagai biossay dalam isolasi senyawa bioaktif dari bahan alam. Majalah Farmasi dan Farmakologi. 6(2): $432-$ 436

Angka, S.L. dan Suhartono, M.T. 2000. Bioteknologi Hasil Laut. Pusat Kajian Sumberdaya Pesisir dan Lautan Institut Pertanian Bogor. Bogor. 149 pp
Atmadja, W S., Kadi, A., Sulistijo dan Rachmaniar. 1996 Pengenalan Jenis-jenis Rumput Laut Indonesia. Puslitbang Oseanologi - LIPI. Jakarta.191pp.

Carballo, J.L., Hernadez-Inda, Z.L., P. Perez, and GarciaGravalos, M.D. 2002. A comparison between two brine shrimp assay to detect in vitro cytotoxicity in marine natural product (methodology article). BMC Biotechnology. 2: 1-5

Chow, S.T. Chaw, W.W. and Chung, Y.C. 2003. Antioxidant activity and safety of $50 \%$ ethanolic red bean extract (Phaseolus raditus L, Var Aurea). J. Food Sci. $68(1): 21-25$

Dai, M. 2004. Uji Aktivitas Antiproliperatif Pentagamavunon-O Terhadap Sel Raji, Sel HeLa, dan Myeloma. Tesis Program Pascasarjana, UGM, Yogyakarta.

Guerrero, R.O., Khan, M.T.H., Casanas, B. and Morales, M. 2004. Specific bioassay with selected plants of Bangladesh. Rev.Cubana Plant Med. 9(2): 5-13.

Hughes, D. and Mehmet. H. 2003. Cell proliferation and apoptosis. Advanced Method. BIOS Scientific Publisher Ltd, Oxford. $373 \mathrm{pp}$.

Jadulco, R.C. 2002. Isolation and Structure Elucidation of Bioactive Secondary Metabolites from Marine Sponges and Sponges-derived Fungi. Dissertation. Der Bayerischen Julius-Maximilians, Universitat Wurzburg. Wurzburg. 174 pp.

Jha, R.K. and Zi-rong, X. 2004. Biomedical compounds from marine organisme. Marine Drugs. 2: 123-146.

Kamiya, H., Endo, Y. Muramoto, K., Uchida, H., Sasaki, T., Uchida. N.A. and Raj, U. 1987. Antitumor activity of the macromolecular fraction from a Fijian Tunicate Didemnum varians. Nippon Suisan Gakkaishi. 53(3): 493-496

Maryati, M.S. 2004. Isolasi dan Identifikasi Senyawa Aktif Dalam Rumput Laut Spesies Caulerpa sertularioides (Vahl) C. Agardh serta uji Antioksidan Terhadap DPPH (1,1-difenil-2-pikrilhidrazil) dan Uji Toksisitas dengan Metode BSLT (Brine Shrimp Lethality Test). Skripsi. Fakultas Farmasi Universitas Pancasila, Jakarta. $59 \mathrm{pp}$

McLaughlin, J.L. and Rogers, L.L. 1998. The use of biological assay to evaluate botanicals. Drug Information J., 32: 513-524

Meyer, A.M.S. 1999. Marine pharmacology In 1998: Antitumor and cytotoxic compounds. The Pharmacologist. 11(4): 159-164

Meyer, B.N. Ferrigni, N.R., Putman, J.E., Jacobsen, L.B., Nichols, D.E., McLauglin, J.L. 1982. Brine shrimp: a convenient general bioassay for active plant constituents. Planta Med 45: 35-34.

Misonou, T., Saitoh, J., Oshiba, S., Tokitomo, Y., Maegawa, M.. Inoue, Y., Hori, H. and Sakurai, T. 2003. UV-absorbing substance in red alga Porphyra yezoensis (Bangialeh. Rhodophyta) block thymine photodimer production. Mar. Biotechnol. 5: 194-200.

Oke, J.M. and Hamburger, M.O. 2002. Screening of some Nigerian medical plants for antioxidant activity using DPPH radical. African Journal of Biomedical Research. 5: 77-79

Panichayupakaranant, P and Kaesuwan, S. 2004. Bioassay-guided isolation of antioxidant constituent from 
Cassia alata L. Leaves. Songklanakarin J. Sci. Tech. 26(1): 103-107.

Rinehart, K.L., Shield, L.S and Parsons, M.C. 1993. Antiviral substances. In Attaway, D.H. and Zaborsky, O.R (eds.). Marine Biotechnology. Vol I. Pharmaceutical and Bioactive Natural Products. Plenum Press, New York. p. 309-342

Schmitz, F.J., Bowden, B.F. and Toth, S.I. 1993. Antitumor and cytotoxic compounds from marine organisms. In Attaway, D.H. and Zaborsky, O.R. (eds.). Marine Biotechnology. Vol I. Pharmaceutical and Bioactive Natural Products. Plenum Press, New York. p. 197. 308

Shoeib, N.A., Bibby, M.C., Blunden, G., Linley, P.A., Swaine, D.J., Wheelhouse, R.T. and Wright, C.W. 2004. In-vitro cytotoxic activities of the mayor bromophenols of the red alga Polysiphonia lanosa and novel synthetic isomers. J. Nat. Prod. Page Est: 4.7. $5 \mathrm{pp}$

Widjhati, R., Supriyono, A dan Subintoro. 2004 Pengembangan Senyawa Bioaktif dari Biota Laut Makalah pada Forum Bioteknologi Kelautan dan Perikanan. Pusat Riset Pengolahan Produk dan Sosial Ekonomi Kelautan dan Perikanan, Departemen Kelautan dan Perikanan. Tanggal 25 Maret 2004. 13 pp

Windono, T., Soedirman, S., Yudawati, U., Ermawati, E., Srielita. A. dan Erawati, T.I. 2001. Uji peredaman radikal bebas terhadap 1,1-difenil-2-pikrilhidrazil (DPPH) dari ekstrak kulit buah dan biji anggur (Vitis vinifera, L). Artocarpus. 1(1): 34-43. 